\title{
A INTERVENÇÃO DO CONGRESSO NACIONAL NA AUTONOMIA DAS AGÊNCIAS REGULADORAS
}

\section{CONGRESS INTERVENTION IN REGULATORY AGENCIES IN BRAZIL}

\author{
NATASHA SCHMITT CACCIA SALINAS ${ }^{1}$
}

\begin{abstract}
RESUMO: Este artigo tem por objetivo analisar como o poder legislativo tem buscado, por meio de sua atividade legislativa, intervir na autonomia dos órgãos reguladores. Parte-se, neste artigo, da hipótese de que o poder legislativo, insatisfeito com o arranjo institucional vigente, age estrategicamente para afastar as agências reguladoras da ingerência do poder executivo. $O$ artigo desenvolve um estudo qualitativo de leis e especialmente proposições legislativas de iniciativa parlamentar que buscam afetar diretamente a autonomia das agências reguladoras. As leis e proposições legislativas analisadas neste artigo foram divididas em categorias que representam diferentes formas de intervenção na autonomia das agências. Para responder ao problema proposto, o artigo subdivide-se em duas partes. Na primeira, apresenta-se uma breve revisão teórica sobre controle legislativo da administração pública. As estratégias de controle político que afetam diretamente aautonomia das agências reguladoras são analisadas em abstrato. Na segunda parte, analisa-se a produção legislativa do Congresso Nacional sobre autonomia regulatória. Pretendese, com este estudo, qualificar o debate sobre autonomia das agências reguladoras no Brasil. Ver-se-á que a autonomia das agências reguladoras é um conceito em disputa, sensível às transformações nas relações entre poder legislativo, poder executivo e agências reguladoras.
\end{abstract}

Palavras-Chave: Autonomia; Agências Reguladoras; Legislação; Congresso Nacional; Poder Executivo.

1 Professora do Mestrado em Direito da Regulação e do curso de graduação da FGV Direito Rio. Doutora e Mestre em Direito pela USP. Master of Laws pela Yale University. Contato: natasha.salinas@fgv.br. 
ABSTRACT: This article aims to analyze how the legislative power has been trying to intervene in the autonomy of regulatory agencies through its legislative activity. This article aims to test the hypothesis under which the legislative power, unsatisfied with current institutional arrangements, acts strategically to insulate regulatory agencies from the influence of the executive power. The article develops a qualitative study based on the legislative history of statutes and bills that have an impact on the autonomy of regulatory agencies. The statutes and bills herein analyzed were sorted by categories that represent the different forms of intervention on the autonomy of regulatory agencies. To answer the research question here proposed, the article is divided into two parts. The first reviews the literature on legislative control of bureaucracy. The second part empirically describes the legislative production of the Brazilian Congress that directly affects the autonomy of regulatory agencies. It is expected, with this study, to enhance the debate on the autonomy of regulatory agencies in Brazil. Autonomy is not a panacea, it entails multiple meanings and it is sensitive to the transformations on the relationship between the legislative power, the executive power and regulatory agencies.

KEYWORDS: Autonomy; Regulatory Agencies; Legislation; Congress; The Executive Power.

\section{INTRODUÇÃO}

A autonomia das agências reguladoras é um tema muito citado, porém pouco compreendido no Brasil. O modelo de Estado Regulador instituído nas últimas décadas fez crer que as agências reguladoras seriam entidades dotadas de autonomia administrativa, financeira, patrimonial e, sobretudo, decisória.

A própria definição de agência reguladora independente pressupõe o reconhecimento desta autonomia. Afinal, o que diferencia uma agência reguladora de outros órgãos da Administração seria justamente essa autonomia multifacetária que lhe é atribuída.

A prática de atuação das agências reguladoras tem revelado, no entanto, que esta autonomia em várias situações é mais formal do que real. O exemplo da autonomia orçamentária é ilustrativo. É sabido que as agências reguladoras não dispõem, na prática, de autonomia para gastar os recursos que arrecadam. Parcela significativa destes recursos são contingenciados pelo poder executivo para cumprir metas de 
superávit primário. A autonomia financeira das agências é, portanto, severamente comprometida por ingerência política.

Na prática, verifica-se que a autonomia das agências reguladoras é mais formal do que real. Essa autonomia é severamente limitada por arranjos institucionais vigentes que permitem, especialmente ao poder executivo, controlar a atuação das agências reguladoras.

Este artigo, no entanto, dá ênfase à intervenção do poder legislativo na autonomia das agências reguladoras. Parte-se, neste artigo, da hipótese de que o poder legislativo, insatisfeito com o arranjo institucional vigente, age estrategicamente para afastar as agências reguladoras da ingerência do poder executivo.

Este artigo desenvolve um estudo qualitativo de leis e especialmente proposições legislativas de iniciativa parlamentar que buscam afetar diretamente a autonomia das agências reguladoras. As leis e proposições legislativas analisadas neste artigo foram divididas em categorias que representam diferentes formas de intervenção na autonomia das agências.

As cinco dimensões da autonomia das agências que são objeto de tentativas de intervenção pelo Congresso Nacional são: autonomia orçamentária, de pessoal, organizacional, decisória (processual) e funcional (competências).

Foge aos propósitos deste artigo analisar normativamente a autonomia das agências, seja em relação ao poder executivo, sejam em relação ao poder legislativo. Não se pretende, portanto, defender ou rejeitar uma maior autonomia das agências reguladoras em relação a esses poderes. Tem-se aqui um objetivo mais modesto, porém necessário, inclusive para embasar análises normativas futuras: trata-se da apresentação de um diagnóstico que permita conhecer os arranjos institucionais em disputa pelos poderes legislativo e executivo que interferem na autonomia das agências reguladoras federais.

Não se pretende, com essa análise, mensurar o sucesso da intervenção do poder legislativo na autonomia das agências reguladoras. O objetivo principal deste artigo é descrever a variabilidade de arranjos institucionais em disputa pelos agentes políticos para intervir na autonomia das agências reguladoras.

Para cumprir esse propósito, este artigo subdivide-se em duas partes. Na primeira, apresenta-se uma breve revisão teórica sobre controle legislativo da administração pública. Analisa-se, em caráter abstrato, algumas das estratégias de controle político das agências reguladoras. Na segunda parte, analisam-se iniciativas legislativas sobre autonomia orçamentária, de pessoal, organizacional, decisória (processual), e funcional (competências) que oram ampliam, ora restringem a autonomia das agências reguladoras. Pretende-se, com essa análise, qualificar o debate sobre autonomia das agências reguladoras no Brasil. 


\section{INSTRUMENTOS DE CONTROLE DA AUTONOMIA DAS AGÊNCIAS REGULADORAS}

É possível identificar duas visões contrapostas na literatura acerca da autonomia das agências reguladoras: uma que descreve as agências reguladoras como independentes dos demais poderes estatais e outra que as percebe como controladas pelos mesmos.

A primeira corrente enfatiza a autonomia das agências reguladoras em relação aos demais poderes, especialmente em relação ao poder legislativo. Nessa perspectiva, as agências estariam insuladas dos demais poderes, não respondendo assim às ingerências de atores políticos, como parlamentares, ministros de estado e o Presidente da República.

As agências reguladoras seriam, portanto, uma espécie de poder independente, a que alguns denominam de "Estado Administrativo". ${ }^{2}$

Para os adeptos dessa corrente, a autonomia das agências reguladoras é, em alguma medida, inevitável: ainda que indesejável, esta é impulsionada pelo fato de que agências implementam políticas públicas e, nessa condição, assumem responsabilidades que os agentes políticos não têm a intenção de desempenhar (NISKANEN, 1971).

A autonomia das agências reguladoras seria também impulsionada pelo profissionalismo de seus servidores. Exigências para ingresso na carreira, alto nível de especialização funcional, bem como acúmulo de experiência proporcionado por tempo de serviço contribuem para que servidores públicos estejam mais capacitados do que parlamentares e governantes eleitos para solucionarem problemas complexos e rapidamente cambiantes.

Há quem veja vantagens no fato de agências reguladoras poderem agir de forma autônoma e independente dos governantes eleitos. $\mathrm{O}$ argumento principal defendido pelos adeptos dessa corrente é o de que o conhecimento altamente especializado dos servidores das agências reguladoras tende a produzir políticas públicas mais coerentes (CALDWELL; MOE, 1994). Para outros, burocracias autônomas estão mais

\footnotetext{
2 A expressão "Estado Administrativo" foi cunhada por Dwight Waldo (1948) para se referir a uma Administração Pública que concentra em si atividades típicas dos três poderes de um Estado. Esta expressão é hoje amplamente adotada nos Estados Unidos, mas é evitada pela literatura jurídica brasileira, talvez porque remeta à ideia - incompatível com uma visão rígida da separação de poderes - de que a Administração Pública exerça funções quase-legislativas ou quase-judicantes. A expressão "quarto poder" também é adotada por autores norte-americanos com objetivos semelhantes.
} 
aptas a inovar administrativamente, beneficiando, portanto, a sociedade (SACKS, 1980).

Há ainda aqueles que defendem o insulamento das agências não pelo argumento técnico, mas pelo argumento institucional: as instituições políticas são desenhadas de tal modo que governantes e parlamentares eleitos estariam menos aptos do que os burocratas a formularem políticas públicas em prol de interesses coletivos e sociais (MASHAW, 1997).

Segundo essa corrente, portanto, a autonomia das agências reguladoras em relação aos agentes políticos seria o melhor arranjo institucional para a promoção do interesse público, sendo plenamente compatível com valores democráticos.

Em direção contrária, há a corrente que defende que as agências reguladoras não agem, ou não deveriam agir, autonomamente. Para seus adeptos, o insulamento burocrático seria incompatível com valores democráticos, na medida que burocratas assumem posições privilegiadas no processo de implementação de políticas públicas (LIPSKY, 1980) que lhes permitem agir de forma nem sempre alinhada com os interesses dos governantes e parlamentares eleitos. As assimetrias de conhecimento, informação e tempo disponível entre burocratas e agentes políticos permitem que os primeiros por vezes tomem decisões contrárias aos interesses dos últimos.

Burocratas podem, assim, fazer uso do conhecimento e das competências de que dispõem para agirem em benefício de interesses da classe capitalista (POULANTZAS, 1978), das organizações a que pertencem (SELZNICK, 1949; WILSON, 1980), ou até mesmo interesses próprios, que poderão ou não coincidir com os interesses dos governantes eleitos e de seus constituintes.

Os argumentos favoráveis ou desfavoráveis à autonomia burocrática costumam, especialmente na literatura internacional, amparar-se em análises empíricas. Esses estudos procuram demonstrar se a Administração age ou não de forma autônoma ao poder legislativo e quais as consequências dessa atuação.

Huber e Shipan (2002), no entanto, ressaltam as dificuldades em se comprovar empiricamente a autonomia administrativa das agências a partir dos seus aspectos institucionais.

O fato de agências usufruírem de autonomia financeira, administrativa, patrimonial e decisória não as coloca necessariamente em posição contrária aos interesses dos agentes políticos. É possível identificar agências que, não obstante usufruam de independência formal, agem de forma alinhada com os interesses dos agentes políticos e de seus constituintes. Essas agências seriam independentes do ponto de vista formal, mas suas ações não seriam propriamente autônomas.

Admite-se, portanto, a possibilidade de controle político das agências reguladoras mesmo quando essas são dotadas de autonomia institucional e independência decisória e vice-versa. 
Neste artigo, afasta-se, portanto, da intenção de se comprovar empiricamente se as agências reguladoras agem de fato de forma autônoma e independente dos atores políticos, tampouco pretende-se analisar normativamente as estratégias que conferem maior ou menor autonomia decisória aos órgãos reguladores.

Ao invés disso, este artigo pretende analisar, por meio de exemplos concretos, estratégias mediante as quais o poder legislativo busca intervir na autonomia das agências reguladoras, afastando-as sobretudo da ingerência do poder executivo. A esse respeito, cabe observar que as escolhas que os legisladores fazem sobre arranjos institucionais das agências reguladoras não são neutras. Elas representam, antes de tudo, disputas dos agentes políticos por influência nas políticas regulatórias desempenhadas pelas agências (MOE, 1989, p. 268).

As leis que regem as agências reguladoras refletem escolhas realizadas pelos agentes políticos sobre o grau de autonomia e discricionariedade que será atribuído às agências. As agências podem usufruir de mais ou menos autonomia institucional, a depender dos arranjos institucionais escolhidos.

Como observado, neste artigo analisam-se cinco estratégias por meio das quais atores políticos modulam a autonomia das agências reguladoras: orçamento, pessoal, estrutura, processos e competências.

Sobre a autonomia orçamentária, verifica-se que sua efetividade como instrumento modulador da autonomia das agências depende da natureza dos recursos orçamentários. Quanto mais discricionários forem os recursos orçamentários da agência, mais poder terão os agentes políticos para controlar as ações das agências por meio desse instrumento (SINCLAIR, 2007, p. 111-128). Por exemplo, o chefe do poder executivo, quando insatisfeito com a atuação das agências reguladoras, pode cortar seu orçamento como forma de retaliação. Inversamente, o Presidente da República pode premiar as agências aumentando os seus recursos orçamentários. Para que o poder legislativo possa conter esta atuação interventiva do poder executivo, é preciso restringir a discricionariedade do poder executivo sobre o orçamento das agências.

A ingerência sobre os servidores das agências também é um instrumento que pode afetar a sua autonomia. Esta interferência poderá ser maior ou menor a depender do modo como são definidas as regras de ocupação de cargos e de estruturação das carreiras no interior das agências. As agências podem ou não admitir em sua estrutura administrativa cargos de nomeação política. Em caso afirmativo, é preciso averiguar se essas nomeações políticas são inteiramente discricionárias ou se observam requisitos técnicos que limitam essa discricionariedade. 
A estrutura de carreira das agências reguladoras, com ou sem cargos de nomeação política, também pode contribuir para uma maior ou menor ingerência política sobre as agências. Uma estrutura de carreira fixa, com remuneração satisfatória e que privilegia a experiência e conhecimento técnico dos servidores pode contribuir para uma maior autonomia das agências.

A atuação das agências reguladoras também pode ser diretamente afetada por sua estrutura organizacional. A estrutura organizacional de uma agência indica como se dá a divisão de trabalho no seu interior, quais os papéis e atribuições devem ser assumidos pelos servidores alocados em diferentes unidades organizacionais, bem como estabelece as formas de comunicação entre os membros da agência e entre seus servidores e a população externa. (EGEBERG, 2003).

Os agentes políticos interferem na estrutura organizacional das agências no ato de criação delas, por meio da edição das leis-quadro que as regem, bem como ao proporem reformas que diretamente afetem sua organização administrativa. Essas reorganizações podem ser utilizadas intencionalmente para aumentar ou diminuir a autonomia das agências reguladoras.

Os processos por meio dos quais as agências tomam as suas decisões também são percebidos como "verdadeiros instrumentos de controle político" desses órgãos (MCCUBBINS; NOLL; WEINGAST, 1987).

Trata-se de uma análise muito distinta da tradicionalmente conferida pela literatura jurídico-administrativista. A visão jurídica tradicional percebe os processos administrativos como instrumentos para conferir legitimidade às decisões administrativas, limitar a discricionariedade dos agentes públicos e proteger os cidadãos contra ações arbitrárias do Estado (MEDAUAR, 2008).

Dada a impossibilidade, pelos motivos já citados, dos agentes políticos de decidir questões tecnicamente intricadas, esses delegam poder decisório para as agências sem, no entanto, perder controle sobre a atividade regulatória. Os processos administrativos seriam, desse modo, meios mediante os quais agentes políticos estariam controlando a atividade decisória das agências sem que precisem conhecer o conteúdo destas decisões.

Cabe observar, no entanto, que não há consenso na literatura sobre as potencialidades dos processos administrativos para controlar a atividade de produção normativa desempenhada pelos órgãos reguladores. Os pontos mais controvertidos dizem respeito ao papel facilitador ou obstrutor (MOE, 1989) dos processos incidentes sobre as decisões dos órgãos reguladores.

Por fim, os agentes políticos podem afetar a autonomia das agências reguladoras por meio da criação, ampliação, modificação e redução de suas competências. Essas competências poderão ser mais ou menos discricionárias, a depender da extensão da delegação de poderes dos agentes políticos para as agências. 


\section{Metodologia}

Parte das leis e proposições legislativas analisadas neste trabalho foram selecionadas em estudo empírico anterior, que procurou mensurar a produção legislativa do Congresso Nacional sobre agências reguladoras (JORDÃO; MOLHANO; SAMPAIO; SALINAS, 2019).

As proposições legislativas selecionadas para o referido estudo foram extraídas da base de dados da Câmara dos Deputados, disponibilizada pública e gratuitamente por meio da internet ${ }^{3}$.

Essas proposições legislativas foram, na ocasião, lidas na íntegra e subdivididas em cinco temáticas, referidas no estudo prévio como orçamento, institucional, pessoal, controle e competências/regulação. Este artigo aproveita-se, com adaptações, da classificação realizada no referido estudo para analisar a autonomia orçamentária, organizacional, de gestão de pessoas, decisória e funcional.

O estudo desenvolvido neste artigo, no entanto, diferencia-se do anterior já que se propõe a analisar qualitativamente as leis e proposições legislativas representativas das diferentes formas de intervenção na autonomia das agências reguladoras. Para os propósitos deste artigo, foi selecionada uma mostra não probabilística do conjunto de iniciativas legislativas produzidas pelo Congresso Nacional envolvendo agências reguladoras. Foram selecionadas algumas leis e proposições legislativas para cada uma das modalidades de restrição da autonomia das agências reguladoras acima referidas. Além disso, foram também selecionadas proposições legislativas originárias ou em trâmite no Senado Federal, não contempladas no estudo previamente mencionado prévio. ${ }^{4}$

3 Uma explicação detalhada da metodologia empregada no referido estudo pode ser facilmente consultada (JORDÃO; MOLHANO; SAMPAIO; SALINAS, 2019). Para a busca dessas proposições, foram utilizadas as palavras-chave "Agências Reguladoras", "Regulação", "Anatel", "Aneel", "Ancine", "Anac", "Antaq", "Antt", "Anvisa", "Ans", "Ana", "Anm" e "Anp". A base da Câmara dos Deputados está em: http://www.camara.leg.br/buscaProposicoesWeb/pesquisaAvancada. Já a base do Senado Federal está disponível em: https://www25.senado.leg.br/web/atividade. Acesso em: 30 out. 2018.

${ }^{4}$ Já a base do Senado Federal está disponível em: https://www25.senado.leg.br/web/atividade. Acesso em: 30 out. 2018. 


\section{CONTROLE LEGISLATIVO DA AUTONOMIA DAS AGÊNCIAS REGULADORAS}

\section{Autonomia financeira}

O modelo de Estado Regulador instituído a partir do final da década de 1990 foi concebido a partir da ideia de que as agências reguladoras teriam autonomia financeira.

As leis-quadro que disciplinam as agências geralmente estabelecem as suas fontes de receita. Estas leis garantem às agências orçamentos independentes dos ministérios a que estão vinculadas, bem como lhes confere o direito de gerar receita por meio da arrecadação de taxas de fiscalização, cobrança de multas e concessão de outorgas aos agentes regulados.

Nas últimas décadas, as agências reguladoras têm sido bem-sucedidas na geração de receitas próprias, suficientes para cobrir suas despesas obrigatórias e discricionárias. Ocorre, no entanto, que parcela considerável das despesas discricionárias é contingenciada para cumprir metas de superávit primário (XAVIER, 2011). Pelo regime estabelecido na Lei de Responsabilidade Fiscal (BRASIL, 2000b), o contingenciamento de recursos orçamentários para cumprir metas de responsabilidade fiscal se aplica universalmente a todos os órgãos no âmbito do orçamento fiscal e de seguridade social. As agências reguladoras têm sofrido com essas ações de contingenciamento, não obstante arrecadem recursos suficientes para custear todas as suas despesas discricionárias.

Essas regras terminam, portanto, por limitar a autonomia das agências. A limitação não decorre das leis que regem as agências, mas sim da legislação financeira, notadamente a Lei de Responsabilidade Fiscal (BRASIL, 2000b).

É neste contexto que têm surgido iniciativas legislativas no Congresso Nacional com o objetivo de reverter este quadro. O deputado Antonio Carlos Mendes Thame, por exemplo, apresentou nos seus mandatos alguns projetos de lei complementar visando alterar a Lei de Responsabilidade Fiscal para excluir as agências reguladoras do contingenciamento de recursos para cumprimento de metas de resultado primário. O projeto de lei complementar da Câmara dos Deputados n. 7/11 (BRASIL, 2011c), o mais recente dessa natureza apresentado pelo referido deputado, foi rejeitado no mérito pela Comissão de Finanças e Tributação com fundamento no princípio da universalidade da aplicação da regra de contingenciamento.

Como alternativa à proposta de contingenciamento orçamentário, têm tramitado no Congresso Nacional propostas que visam a tornar as receitas provenientes da aplicação de multas e cobrança de taxas pelas agências como despesas obrigatórias. 
Os projetos de lei da Câmara dos Deputados n. 3.041/15 (BRASIL, 2015c) e 5185/16 (BRASIL, 2016a), buscam vincular parcela da receita arrecadada pelo Fundo de Fiscalização das Telecomunicações (FISTEL) ao custeio da ANATEL.

As iniciativas legislativas que têm por objetivo vincular receitas às agências reguladoras ou proibir o contingenciamento orçamentário têm em comum o fato de que visam a ampliar a autonomia financeira das agências. Essas proposições, de iniciativa do poder legislativo, correspondem a uma reação dos congressistas brasileiros às reais limitações na autonomia financeira das agências.

No entanto, os parlamentares também têm proposto iniciativas legislativas que visam a limitar a autonomia financeira das agências em outros moldes. A esse respeito, têm tramitado no Congresso Nacional, com alguma frequência, projetos de lei que vinculam receitas arrecadadas pelas agências para a execução de políticas públicas específicas. Diferentemente das iniciativas anteriormente mencionadas, que procuram vincular as receitas arrecadadas com multas para o custeio de despesas gerais da agência, esses projetos visam a destinar tais recursos para serviços públicos específicos, como serviços de banda larga em áreas não rentáveis ${ }^{5}$ ou em áreas rurais ${ }^{6}$ (PL 5867/2001), financiamento do SUS7 e para financiar novos fundos setoriais ${ }^{8}$ (PL 4273/2004 e PL 5514/2009).

Os congressistas, ao tentarem vincular as receitas orçamentárias das agências reguladoras e programas e políticas públicas específicas, buscam, por meio das leis que editam, influenciar as políticas regulatórias.

Cabe observar, no entanto, que até o presente momento nenhuma das iniciativas sobre os temas citados nesta seção foi convertida em norma jurídica. A autonomia financeira das agências reguladoras permanece limitada pela legislação de responsabilidade fiscal vigente que, como visto, permite ao poder executivo contingenciar recursos arrecadados pelas próprias agências.

\section{Autonomia na gestão de pessoas}

O Assim como as normas sobre orçamento, as regras sobre pessoal podem tanto ampliar como reduzir a autonomia das agências reguladoras.

A Lei n. 10.871, de 20 de maio de 2004 (BRASIL, 2004a), disciplina as carreiras e os cargos efetivos das agências reguladoras. Essa lei prevê concurso público para a investidura nos cargos, estabelece regras para promoção nas carreiras, define

\footnotetext{
${ }^{5}$ Projeto de Lei da Câmara dos Deputados n. 8.460/2017 (BRASIL, 2017).

${ }^{6}$ Projeto de Lei da Câmara dos Deputados n. 5.867/2001 (BRASIL, 2001).

7 Projeto de Lei da Câmara dos Deputados n. 4.113/2015 (BRASIL, 2015d).

8 Projeto de Lei da Câmara dos Deputados n. 4.273/2004 (BRASIL, 2004) e Projeto de Lei da Câmara dos Deputados n. 5.514 (BRASIL, 2009.
} 
padrões de vencimentos, bem como estabelece direitos e deveres aos servidores. Além do dever de manter sigilo sobre as operações das instituições reguladas, os servidores das agências reguladoras estão proibidos, por força do artigo 23 dessa lei, de prestar serviços para agentes regulados e firmar contrato com essas instituições em situações mais vantajosas do que a de outros usuários. Além disso, o servidor da agência está proibido de exercer outras atividades profissionais, como cargos de gestão em empresas ou partidos políticos. Além disso, com a alteração legislativa que sofreu em 20099 , a Lei n. 10.871/2004 (BRASIL, 2004a) restringiu a ocupação de cargos comissionados técnicos apenas a servidores ocupantes de cargos efetivos.

Para além dos cargos técnicos, as agências reguladoras possuem cargos de natureza política. A investidura nos cargos de Presidência e de membros da Diretoria das agências são, conforme prevê a Lei n. 9.986, de 18 de julho de 2000 (BRASIL, 2000a), de livre escolha do Presidente da República, com aprovação posterior do Senado Federal. São elegíveis para a ocupação desses cargos "brasileiros, de reputação ilibada, formação universitária e elevado conceito no campo de especialidade dos cargos para os quais serão nomeados" (BRASIL, 2000a). Os prazos dos mandatos dos membros da diretoria das agências variam entre si, já que são fixados pelas leis que as regem. O mandato é fixo, de modo que os dirigentes só poderão ser exonerados após condenação transitada em julgado ou processo administrativo disciplinar. ${ }^{10}$ Por fim, após cumprido o exercício do mandato, os ex dirigentes estão impedidos de prestar qualquer serviço ao setor regulado pela agência por um período de quatro meses.

As regras de pessoal que atualmente regem os cargos técnicos e políticos das agências reguladoras, em sua grande maioria, visam, em tese, a garantir a sua autonomia. Mesmo para os cargos políticos, em que a nomeação se dá por ato de livre escolha do Presidente da República e não mediante concurso público, a lei exige conhecimento técnico-especializado para exercício do cargo. Como observado anteriormente, a autonomia das agências reguladoras é impulsionada pelo profissionalismo de seus servidores. A atuação dos servidores das agências reguladoras, embasada por critérios técnicos, estaria supostamente menos suscetível a pressões dos agentes políticos e dos grupos de interesse. ${ }^{11}$ A estabilidade dos cargos técnicos e o mandato fixo dos cargos políticos contribuiriam, igualmente, para a autonomia da agência reguladora. As pessoas que ocupam estes cargos tendem,

\footnotetext{
${ }^{9}$ A Lei n. 11.907/2009 (BRASIL, 2009a) alterou a Lei n. 10.871/2004.

10 Algumas agências reguladoras admitem a exoneração imotivada apenas nos primeiros meses de mandato, como a Agência Nacional de Águas (BRASIL, 2000).

11 Como visto no item anterior, a autonomia técnico-administrativa é vista por parte da literatura como um problema, e não como uma solução. Foge ao escopo deste trabalho analisar normativamente a independência técnica-administrativa das agências reguladoras.
} 
deste modo, a agir de modo mais independente por não terem suas posições profissionais ameaçadas. Por fim, as regras de pessoal, tal como formuladas, visam a garantir a autonomia das agências reguladoras não apenas em relação aos agentes políticos, mas também em relação aos agentes econômicos regulados. Ocupantes de cargos técnicos e políticos estão impedidos de prestar serviços a entidades reguladas enquanto estiverem exercendo seus cargos. Além disso, ocupantes de cargos políticos permanecem impedidos de prestar tais serviços durante o período de quarentena.

No entanto, as regras do regime de nomeação, exercício e perda do mandato dos cargos políticos estabelecido pela Lei n. 9.986/2000 (BRASIL, 2000a), que supostamente serviriam para assegurar a autonomia das agências reguladoras, não têm sido consideradas satisfatórias pelo poder legislativo.

Tramitam atualmente no Congresso Nacional diversos projetos de lei que buscam impor novos requisitos para a escolha e nomeação dos dirigentes. O projeto de lei do Senado n. 495/2015 (BRASIL, 2015e), por exemplo, exige dos dirigentes experiência profissional e acadêmica de no mínimo cinco anos na área regulada pela agência. Em sentido contrário, mas também visando impor novas critérios para a nomeação de dirigentes, o projeto de lei da Câmara dos Deputados n. 5.737/2013 (BRASIL, 2013) proíbe a nomeação de pessoas que tenham prestado serviços a empresas do setor regulado em qualquer período de tempo compreendido nos dez anos anteriores à nomeação.

Outras iniciativas visam a alterar as regras de escolha dos dirigentes pelo Presidente da República. O projeto de Lei do Senado n. 241/2015 (2015e) propõe que o Senado Federal, e não o Presidente da República, escolha os dirigentes das agências reguladoras. Esse projeto prevê, ainda, que a escolha se dê a partir de listas tríplices elaboradas pelo poder executivo. $\mathrm{O}$ projeto de lei da Câmara dos Deputados n. 5184/2016 (BRASIL, 2016) prevê a escolha dos dirigentes da ANATEL pelo Presidente da República a partir de listas tríplices elaboradas por órgãos estatais, da sociedade civil e do setor regulado. ${ }^{12} \mathrm{O}$ projeto de lei da Câmara dos Deputados n. 4.030/2012 (BRASIL, 2012) estabelece que uma das vagas de diretoria da ANEEL, ANATEL, ANP, ANAC e ANS seja preenchida por representante dos consumidores. A recém aprovada Lei n. 13.848/20019 (BRASIL, 2019a), que dispõe sobre a gestão, organização, processo decisório e controle social das agências reguladoras, previa, em sua versão original, que a escolha dos dirigentes das agências se desse por meio de lista tríplice. A solução adotada por esta lei foi além dos projetos de lei anteriormente mencionados, já que instituiu processo seletivo público para a

\footnotetext{
12 Relacionado a este último projeto de lei, tramita também na Câmara dos Deputados o projeto de lei n. 7529/2014 (BRASIL, 2014), que reserva uma das cinco vagas de diretoria da ANATEL para um representante dos usuários.
} 
formação da lista tríplice. Este dispositivo, no entanto, foi vetado pelo Presidente da República sob o argumento de que feria seu poder de indicar livremente os dirigentes das agências reguladoras (BRASIL, 2019).

Há também iniciativas que pretendem modificar as regras de quarentena. $\mathrm{O}$ projeto de lei do Senado Federal n. 495/2015 (BRASIL, 2015f), que se aplica a todas as agências reguladoras, pretendia ampliar o prazo de quarentena de quatro meses para um ano. A recém aprovada Lei n. 13.848/2019 (BRASIL, 2019ª) terminou por ampliar este prazo para seis meses.

O projeto de lei do Senado Federal n. 495/2015 (BRASIL, 2015f) pretendia estabelecer prazo de mandato de quatro anos para os dirigentes de todas as estatais. ${ }^{13}$ A Lei n. 13.848/2019, recém aprovada, alterou a Lei n. 9.986/2000 neste particular, ampliando o prazo de mandato dos dirigentes de todas as agências para cinco anos.

Por fim, o Congresso Nacional buscou estabelecer prazos para que o Presidente da República escolhesse um novo dirigente em caso de vacância no cargo (decorrente ou não do término do mandato). O art. 42 da Lei n. 13.848/2019 estabeleceu prazo de 60 dias para que o presidente escolha um novo dirigente, oporém esse dispositivo foi vetado pelo Presidente da República sob o argumento de que feria seu poder de livre indicar dirigentes das agências reguladoras.

As iniciativas legislativas citadas reforçam um sentimento de insatisfação dos membros do poder legislativo com as regras atuais de escolha e nomeação dos dirigentes. À primeira vista, é possível sustentar que esses projetos buscam tornar a atuação das agências reguladoras mais neutra e insulada do Presidente da República. Ao enfatizarem a profissionalização das agências, esses projetos são apresentados como fórmulas ou soluções para coibir práticas clientelistas de loteamento de cargos. Mas eles podem, igualmente, apenas representar uma disputa entre os poderes executivo e legislativo pelo controle das agências. Afinal, esses projetos têm em comum o fato de que limitam a discricionariedade que hoje o Presidente da República possui tanto para escolher quanto para protelar a escolha dos dirigentes das agências reguladoras.

\section{Autonomia organizacional}

A autonomia das agências reguladoras também é diretamente afetada pela sua estrutura organizacional.

Não seria possível, aqui, descrever as diversas estruturas organizacionais das agências reguladoras. Essas são disciplinadas pelas leis instituidoras das agências, não havendo uma lei geral que trate destes aspectos organizacionais.

${ }^{13}$ Este prazo hoje é determinado pelas leis que regem cada agência. 
Em um sobrevôo pelas leis que regem as agências, verifica-se que é delegado aos órgãos reguladores definir as "regras do jogo" do seu processo decisório e de sua estrutura organizacional. As leis disciplinam vagamente a estrutura organizacional das agências reguladoras, permitindo assim que elas preencham essa lacuna normativa por meio de normas de organização interna. Uma possível explicação para o descaso dos atores políticos com o disciplinamento de regras organizacionais talvez resida no fato de que essas normas não são percebidas como instrumentos potencialmente capazes de afetar os resultados das políticas implementadas pelas agências. Regras sobre estrutura, organização e funcionamento interno da Administração são frequentemente percebidas como questões de menor importância, as quais podem ser disciplinadas por normas de hierarquia inferior, ou até mesmo nem ser disciplinadas. Uma outra possível explicação, em sentido oposto, pode residir no fato de que regras estruturais são formuladas de modo displicentemente vago como uma atitude racional da Administração Pública de não limitar a si mesma, bem como de não publicizar e democratizar suas práticas decisórias, a menos que seja constrangida a tanto.

No entanto, a recém aprovada Lei n. 13.848/2919 (BRASIL, 2019ª), que dispõe sobre a gestão, organização, processo decisório e controle social das agências reguladoras introduziu uma ouvidoria nas agências reguladoras para apurar denúncias e reclamações contra as agências reguladoras. Este projeto prevê que o cargo de ouvidor deve se sujeitar a processo de nomeação política, com escolha do Presidente da República e confirmação do Senado Federal.

Em anos próximos à criação das agências reguladoras, o local da sede dos órgãos reguladores também foi objeto de disputa entre congressistas. A ANP, no momento da sua instituição, tinha sede na cidade do Rio de Janeiro. Alguns anos após sua criação, parlamentares propuseram iniciativas legislativas visando alterar a sede da agência para Brasília. O deputado federal José Roberto Arruda, que apresentou três projetos de lei com este propósito, justificou a sua proposição com base no argumento de que a instalação da ANP no Rio de Janeiro colocaria "em risco a própria eficiência do órgão" (BRASIL, 2003). Para o deputado, todas as agências reguladoras deveriam ter sede em Brasília, para se manterem distantes de "pressões regionais". A sede da ANP acabou sendo transferida para a capital do país em 2005, com a edição da Lei n. 11.097, de 13 de janeiro 2005 (BRASIL, 2005).

Em contrapartida, projetos de autoria do então deputado Eduardo Paes visavam a alterar a sede da ANEEL (BRASIL, 2003a) e da ANATEL (BRASIL, 2003b) de Brasília para a cidade do Rio de Janeiro. O deputado justificou seu pedido de mudança sob o argumento de que o Rio de Janeiro concentrava a "inteligência dos setores de telecomunicações e energia elétrica do Brasil". Essas mudanças, embora não tenham 
sido aprovadas pelo Congresso Nacional, foram objeto de disputa pelo controle organizacional da agência.

\section{Autonomia decisória (processual)}

As normas processuais que regem a tomada de decisão das agências também podem ter reflexos na sua autonomia administrativa.

O poder legislativo pode delegar, inclusive de forma ampla, poder decisório às agências reguladoras, sem, no entanto, abrir mão de definir os processos por meio dos quais essas normas serão produzidas. Nessas situações, o poder legislativo limita procedimentalmente - e não materialmente - a discricionariedade das agências reguladoras no que diz respeito à atividade de produção normativa.

O controle pelo procedimento é uma das formas de condicionamento da atuação administrativa. A ideia é a de que a decisão final será impactada pelo procedimento por meio do qual ela é produzida.

Um exemplo de norma processual que pode afetar a autonomia das agências reguladoras é a análise de impacto regulatório. A análise de impacto regulatório, em linhas muito breves, consiste num processo metódico que obriga o formulador da norma a demonstrar que os instrumentos legais que pretende introduzir (e.g. regras exigindo, estimulando ou proibindo determinadas condutas dos agentes econômicos) serão potencialmente aptos a atingir as finalidades normativas. A análise de impacto regulatório requer do formulador a identificação clara dos problemas que a norma pretende solucionar, dos objetivos que esta pretende atingir, e dos meios que serão empregados para resolver estes problemas e realizar estas finalidades. A análise de impacto regulatório requer, ainda, que sejam realizados prognósticos acerca dos efeitos da norma e do seu potencial impacto no tecido social.

Até o presente momento, o poder legislativo não exigiu que as agências reguladoras realizem obrigatoriamente análise de impacto regulatório de sua produção normativa. A análise de impacto regulatório vem sendo adotada por iniciativa das próprias agências reguladoras. Além da Anvisa, primeira agência a adotar análise de impacto regulatório no Brasil, agências como ANS, ANEEL, ANATEL, ANCINE, ANAC, ANP e ANTT desenvolveram projetos pilotos de análise de impacto, com forte apoio institucional do governo federal, por meio do Programa de Melhoria do Processo de Regulamentação (PROREG). No entanto, tramitam no Congresso Nacional algumas iniciativas legislativas que visam a tornar obrigatório o uso de AIR para todas as agências reguladoras.

O projeto de lei da Câmara dos Deputados n. 1.539/2015 (BRASIL, 2015a) visava a tornar a análise de impacto regulatório obrigatória para a edição de atos normativos, planos setoriais e atos que editem, prorroguem ou alterem outorgas de delegação de 
serviços públicos. Segundo esse projeto de lei, a análise de impacto regulatório só poderia ser dispensada de atos normativos de efeito concreto e de normas de organização interna. A Lei n. 13.848/2019 (BRASIL, 2019a) terminou por prever a obrigatoriedade da análise de impacto regulatório para a edição de atos normativos. Essa lei delegau, no entanto, para o executivo a definição do conteúdo e metodologia a ser adotado na análise de impacto regulatório.

Outra forma de controlar procedimentalmente as agências consiste em obrigá-las a consultar previamente a população acerca dos atos normativos que pretende editar. À população é dada a oportunidade de influenciar o processo normativo por meio de contribuições escritas ou orais, a depender do procedimento adotado, que visam a aperfeiçoar o conteúdo do texto normativo proposto pela agência.

A realidade brasileira mostra que não há uma padronização entre as normas que regem os processos relativos aos mecanismos de participação das agências reguladoras. A lei federal de processo administrativo, embora vincule toda e qualquer tomada de decisão da Administração Pública a certas exigências (e.g., publicidade e transparência), silencia quanto aos procedimentos a serem adotados em processos decisórios específicos, como os processos normativos conduzidos pelas agências reguladoras federais. De caráter notadamente principiológico, a lei federal de processo administrativo brasileira destoa, portanto, da lei norte-americana, na medida que não estabelece regras processuais para os processos normativos adotados pelas agências reguladoras.

As "leis-quadro" que estabelecem as competências regulatórias das agências tampouco prevêem esses critérios. Essas leis, quando muito, se restringem a prever a adoção, em vários casos facultativa, dos mecanismos de participação no curso dos processos decisórios das agências. Na prática, cada agência reguladora federal define, por meio de normas regimentais, o modus operandi dos seus mecanismos de participação.

A recém aprovada Lei n. 13848/2019 (BRASIL, 2019a) introduziu um regime geral de gestão e controle das agências reguladoras, tornando obrigatória a consulta pública (mecanismos de participação escrito e não presencial) para a produção de atos normativos de interesse geral dos agentes econômicos, consumidores ou usuários dos serviços prestados. leia referida lei também facultou às agências reguladoras a realização de audiências públicas (mecanismos orais e presenciais) para subsidiar sua tomada de decisão. Essa lei também estabeleceu algumas regras procedimentais importantes para as consultas e audiências públicas, como definição de prazo para envio de críticas, sugestões e contribuições, bem como prazo para que a agência oferece uma resposta às contribuições recebidas. 
Além da participação social, os parlamentares têm submetido projetos de lei que visam a ampliar a transparência das agências. O projeto de lei n. 845/2015 (BRASIL, 2015), por exemplo, obriga a ANTT a disponibilizar informações sobre composição tarifária de serviços de transporte rodoviário. O projeto de lei n. 5.810/2013 (BRASIL, 2013a), de aplicabilidade mais ampla, obriga as agências reguladoras a publicarem em seus sites o conteúdo de todas as suas decisões, inclusive as perlocutórias.

Essas normas procedimentais, quando previstas em lei, contribuem para a diminuição da discricionariedade das agências reguladoras quanto às formas de tomada de decisão. Assim como as normas de estrutura organizacional, os processos tendem a ser definidos internamente pelas próprias agências reguladoras por meio de suas normas regimentais e de organização interna. Verifica-se, no entanto, uma tendência do poder legislativo de passar a definir o conteúdo dessas normas em substituição às agências reguladoras.

\section{Autonomia funcional}

Parlamentares delimitam materialmente a atividade das agências reguladoras ao proporem atos legislativos que criam, ampliam, modificam ou reduzem suas competências. Em essência, estas iniciativas, que definem o escopo de atuação das agências, variam conforme o setor regulado e são constantemente revistas.

As competências das agências reguladoras podem ser mais ou menos discricionárias. Isso dependerá da extensão de da delegação de poderes dos agentes políticos para as agências.

As competências amplamente discricionárias são aquelas em que se confere um alto grau de autonomia às agências reguladoras para tomar suas decisões. Essa ocorre quando as leis conferem competências genéricas às agências reguladoras. Isso ocorre, por exemplo, com proposições legislativas que conferem competência às agências para regularem determinado setor ou atividade sem, no entanto, definir os parâmetros e critérios que deverão nortear esta atividade regulatória.

A Lei n. 11.182/2005 (BRASIL, 2005a), por exemplo, estabelece competência para a ANAC regular e fiscalizar a outorga dos serviços aéreos. Essa competência é considerada aqui como ampla, na medida que a lei não estabelece parâmetros e condições a serem observados pela agência para exercício desta regulação. $\mathrm{Na}$ medida que cabe à própria agência definir também a política de aviação civil, os critérios substantivos que deverão orientar as ações regulatórias da agência serão definidos por ela própria.

A opção pela delegação ampla também ocorre em algumas iniciativas que visam a ampliar parte das competências regulatórias das agências. Observa-se, por exemplo, o Projeto de Lei da Câmara dos Deputados n. 2.734/2011 (BRASIL, 2011b), 
atualmente em trâmite na Câmara dos Deputados. Essa proposição legislativa visa a ampliar as competências da ANS para que a agência passe também a regular as atividades dos prestadores de serviços médicos e hospitalares de saúde suplementar. ${ }^{14} \mathrm{O}$ teor desse projeto de lei restringe-se, no entanto, a determinar genericamente essa competência regulatória. A definição dos critérios de aferição da qualidade dos serviços médicos e hospitalares, por exemplo, deverá ser realizada pela própria ANS.

Em alguns casos, a lei não apenas estabelece competências regulatórias às agências, mas condiciona seu exercício a certos parâmetros legais.

Observa-se, por exemplo, o Projeto de Lei n. 2.845/2015 (BRASIL, 2015b), atualmente em trâmite na Câmara dos Deputados. Esse projeto de lei estabelece competência para a ANAC regular o uso de veículos aéreos não tribulados (VANTS) e Drones. Essa competência, no entanto, não é plenamente discricionária. $O$ projeto de lei estabelece, dentre outros parâmetros, que a ANAC deverá garantir o uso destes equipamentos, ainda que por empresas privadas, para fins de pesquisa e desenvolvimento científico.

Nesse caso, a ANAC permanece com a competência para disciplinar o uso desses equipamentos por entidades públicas ou privadas, estabelecendo, por exemplo, as normas de segurança que deverão ser observadas por estes usuários. No entanto, diante dos parâmetros estabelecidos no projeto de lei, a ANAC não poderá editar uma norma que proíba irrestritamente empresas privadas do uso destes equipamentos. A agência reguladora deverá autorizar este uso quando for comprovada a sua finalidade científica.

A discricionariedade decisória das agências é, por fim, consideravelmente diminuída quando o legislador antecipa na lei conteúdos propriamente regulatórios.

A Lei n. 5.991/73 (BRASIL, 1973), em seu artigo 36, $\S 2$ o , proíbe que farmácias que possuam filiais centralizem a atividade de manipulação de medicamentos em apenas um estabelecimento. A Lei n. 9.294/96 (BRASIL, 1996) proíbe, em seu art. 2oㅡ, § 2oㅡ, o uso de cigarros ou qualquer outro produto derivado do tabaco em aeronaves e veículos de transporte coletivo. Essa mesma lei proíbe, em seu art. $3^{\circ}$-A que sejam distribuídos quaisquer tipos de amostra ou brinde destes produtos. Esses dispositivos têm em comum o fato de que proíbem comportamentos de agentes econômicos regulados e limitam a discricionariedade das agências para disciplinar tais comportamentos. Desse modo, as agências que regulam as atividades de transporte aéreo e terrestre devem garantir que os passageiros destes meios de

\footnotetext{
${ }^{14}$ Atualmente, apenas as operadoras de planos de saúde são diretamente reguladas pela ANS. A ANS regula apenas indiretamente os prestadores de serviços, ao estabelecer regras que as operadoras deverão observar ao se relacionarem com estes prestadores.
} 
transporte não usem cigarros e produtos afins. Do mesmo modo, a agência responsável pela vigilância sanitária não poderá autorizar a distribuição gratuita de cigarros, bem como não poderá permitir que farmácias concentrem suas atividades de manipulação em um único estabelecimento. Não há espaço para que essas agências contrariem ou até mesmo flexibilizem estas proibições.

A opção por obrigar, proibir, dispensar ou autorizar certos comportamentos no texto legal podem ter motivações variadas. O poder legislativo pode antecipar comportamentos no texto legal quando esse tem uma certa preferência pelo conteúdo regulatório e quer garantir que essa preferência seja observada pelo órgão regulador. Mas a delegação restrita pode também ser um recurso utilizado para solucionar conflitos ou discordâncias entre o poder legislativo e o órgão regulador. A Lei n. 13.454, de 23 de junho de 2017 (BRASIL, 2017a), que autorizou ${ }^{15}$ a produção, comercialização e consumo de anorexígenos - substâncias utilizadas na composição de remédios para emagrecimento - foi editada com esse propósito. A produção e comercialização desses produtos era permitida no Brasil há décadas até que a ANVISA editou, em outubro de 2011, uma norma (BRASIL, 2011) restringindo o uso de sibutramina e proibindo o uso das demais substâncias. A Lei n. 13.454/2017 (BRASIL, 2017a) foi editada, deste modo, para limitar a discricionariedade da agência na regulação destas substâncias.

\section{CONCLUSÃO}

As discussões que gravitam em torno da autonomia das agências reguladoras, quando distanciadas de uma análise institucional, acarretam dois riscos. Um deles é o de desconsiderar as disputas políticas que gravitam em torno das escolhas sobre autonomia orçamentária, de pessoal, organizacional, decisória e funcional das agências reguladoras. $O$ outro é o de sobrevalorizar a autonomia das agências reguladoras em relação aos agentes políticos.

As proposições legislativas citadas neste trabalho apontam uma tendência do poder legislativo de propor soluções legais que lhe permita exercer maior influência sobre as agências reguladoras e, em contrapartida, afaste-as da ingerência do poder executivo.

No caso específico das normas orçamentárias, o poder legislativo considera as agências reguladoras pouco autônomas para gastar os recursos que arrecadam. No entanto, esses mesmos parlamentares querem vincular parte das receitas arrecadadas

${ }^{15}$ O projeto de lei da Câmara dos Deputados n. 2.431/2011 (BRASIL, 2011a) que deu origem a esta lei tinha inicialmente redação diversa. Seu texto original proibia a ANVISA de vetar a produção e comercialização dos anorexígenos sibutramina, anfepramona, femproporex e mazindol. 
pelas agências para programas e políticas públicas mais amplos, que não necessariamente estão a ela relacionados. Observa-se, portanto, uma tentativa do poder legislativo de tornar as agências mais autônomas em relação às ações de política econômico-orçamentária do executivo, porém não necessariamente independentes das políticas públicas formuladas pelo legislativo.

Quanto às normas sobre pessoal, o poder legislativo tem buscado afastar as agências reguladoras das ingerências do poder executivo, ao estabelecer novos limites e regras para a nomeação de seus dirigentes.

O poder legislativo tem tentado, igualmente, limitar a discricionariedade dos processos de tomada de decisão das agências, impondo regras de transparência, participação social e deveres de motivação e fundamentação de suas decisões.

O poder legislativo por vezes também restringe a autonomia funcional das agências quando limita seu poder normativo para discorrer sobre importantes questões regulatórias.

Verifica-se, portanto, que o poder legislativo tem tentado, por meio de sua atividade legislativa, diminuir a influência do poder executivo sobre as agências reguladoras. Embora a maior parte dessas iniciativas não tenha por ora, logrado sucesso, já que são poucos os atos legislativos convertidos em normas jurídicas, verifica-se que o poder legislativo se movimenta constantemente para controlar as agências reguladoras.

Como se procurou demonstrar neste artigo, o desenho institucional das agências reguladoras é produto de disputas travadas entre poder legislativo e poder executivo para exercer influência sobre as políticas regulatórias. Essas disputas explicam, ao menos em parte, a instabilidade da autonomia orçamentária, de pessoal, organizacional, decisória e funcional das agências reguladoras.

\section{REFERÊNCIAS}

BRASIL (1973). Congresso Nacional. Lei n. 5.991, de 17 de dezembro de 1973. Dispõe sobre o Controle Sanitário do Comércio de Drogas, Medicamentos, Insumos Farmacêuticos e Correlatos, e dá outras Providências. Disponível em: < http://www.planalto.gov.br/ccivil_03/LEIS/L5991.htm>. Acesso em: nov. 2018.

BRASIL (1996). Lei n. 9.294, de 15 de julho de 1996. Dispõe sobre as restrições ao uso e à propaganda de produtos fumígeros, bebidas alcoólicas, medicamentos, terapias e defensivos agrícolas, nos termos do $\S 4^{\circ}$ do art. 220 da Constituição Federal. 
Disponível em: < http://www.planalto.gov.br/ccivil_03/LEIS/L9294.htm>. Acesso em: nov. 2018.

BRASIL (2000). Lei n. 9.984, de 17 de julho de 2000. Dispõe sobre a criação da Agência Nacional de Águas - ANA, entidade federal de implementação da Política Nacional de Recursos Hídricos, de coordenação do Sistema Nacional de Gerenciamento de Recursos Hídricos e responsável pela instituição de normas de referência nacionais para a regulação da prestação dos serviços públicos de saneamento básico. Disponível em: < http://www.planalto.gov.br/ccivil_03/Leis/L9984.htm>. Acesso em: out. 2018.

BRASIL (2000a). Lei n. 9.986, de 18 de julho de 2000.

Dispõe sobre a gestão de recursos humanos das Agências Reguladoras e dá outras providências. Disponível em: <

http://www.planalto.gov.br/ccivil_03/Leis/L9986.htm>. Acesso em: out. 2018.

BRASIL (2000b). Congresso Nacional. Lei Complementar n. 101, de 4 de maio de 2000. Estabelece normas de finanças públicas voltadas para a responsabilidade na gestão fiscal e dá outras providências. Disponível em: <

http://www.planalto.gov.br/ccivil_03/leis/LCP/Lcp101.htm>. Acesso em: out. 2018.

BRASIL (2001). Câmara dos Deputados. Projeto de Lei n. 5.867/2001. Acrescenta o artigo 53-A à Lei no 9.472, de 16 de julho de 1997, 6 dez. 2001. Disponível em: < http://www.camara.gov.br/proposicoesWeb/fichadetramitacao?idProposicao $=42508$ > . Acesso em: out. 2018.

BRASIL (2003). Câmara dos Deputados. Projeto de Lei n. 1.979/2003.

Dispõe sobre a sede da Agência Nacional do Petróleo - ANP, 15 set. 2003. Disponível em: $<$

http://www.camara.gov.br/proposicoesWeb/fichadetramitacao?idProposicao=133288 >. Acesso em: out. 2018.

BRASIL (2003a). Câmara dos Deputados. Projeto de Lei n. 2.837/2003. Dá nova redação ao art. 1ํ da Lei no 9.427, de 26 de dezembro de 1996, transferindo a sede da Agência Nacional de Energia Elétrica para o Rio de Janeiro, 18 dez. 2003. Disponível em: $<$ 
http://www.camara.gov.br/proposicoesWeb/fichadetramitacao?idProposicao=150059 >. Acesso em: out. 2018.

BRASIL (2003b). Câmara dos Deputados. Projeto de Lei n. 2.838/2003. Dá nova redação ao art. 8o da Lei nº 9.472, de 16 de julho de 1997, transferindo a sede da Agência Nacional de Telecomunicações para o Rio de Janeiro, 18 dez. 2003.

Disponível em: <

http://www.camara.gov.br/proposicoesWeb/fichadetramitacao?idProposicao=150060 >. Acesso em: out. 2003.

BRASIL (2004). Câmara dos Deputados. Projeto de Lei n. 4.273/2004. Autoriza o Poder Executivo criar o Fundo Nacional para a Manutenção dos Transportes, 19 out. 2004. Disponível em: <

http://www.camara.gov.br/proposicoesWeb/fichadetramitacao?idProposicao=266947 >. Acesso em: out. 2018.

BRASIL (2004a). Congresso Nacional. Lei n. 10.871, de 20 de maio de 2004. Dispõe sobre a criação de carreiras e organização de cargos efetivos das autarquias especiais denominadas Agências Reguladoras, e dá outras providências. Disponível em: < http://www.planalto.gov.br/ccivil_03/_Ato2004-2006/2004/Lei/L10.871.htm>. Acesso em: out. 2018.

BRASIL (2005). Congresso Nacional. Lei n. 11.097, de 13 de janeiro de 2005. Dispõe sobre a introdução do biodiesel na matriz energética brasileira; altera as Leis $\mathrm{n}^{\text {os }} 9.478$, de 6 de agosto de 1997, 9.847, de 26 de outubro de 1999 e 10.636, de 30 de dezembro de 2002; e dá outras providências. Disponível em: < http://www.planalto.gov.br/ccivil_03/_Ato2004-2006/2005/Lei/L11097.htm>. Acesso em: out. 2013.

BRASIL (2005a). Congresso Nacional. Lei n. 11.182, de 27 de setembro de 2005. Cria a Agência Nacional de Aviação Civil - ANAC, e dá outras providências. Disponível em: http://www.planalto.gov.br/ccivil_03/_ato2004-2006/2005/Lei/L11182.htm. Acesso em: nov. 2018.

BRASIL (2009). Câmara dos Deputados. Projeto de Lei n. 5514/2009. Autoriza as Agências Reguladoras a remunerar os Conselhos de Consumidores pertinentes às

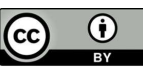


suas áreas de atuação nas condições que especifica, 30 jun. 2009. Disponível em: http://www.camara.gov.br/proposicoesWeb/fichadetramitacao?idProposicao $=440382$. Acesso em: 03 ago. 2018.

BRASIL (2009a). Congresso Nacional. Lei n. 11.907, de 2 de fevereiro de 2009. Disponível em: http://www.planalto.gov.br/ccivil_03/_Ato20072010/2009/Lei/L11907.htm. Acesso em: out. 2009.

BRASIL (2011). Agência Nacional da Vigilância Sanitária. Resolução da Diretoria Colegiada n. 50, de 25 de setembro de 2014. Disponível em: < http://portal.anvisa.gov.br/documents/33880/2568070/reprdc0050_25_09_2014.pdf/d0 4dec76-4dbb-4d04-a721-50bd191a1a9b?version=1.0>. Acesso em: nov. 2018. BRASIL (2011a). Câmara dos Deputados. Projeto de Lei n. 2.431/2011. Proíbe a Agência Nacional de Vigilância Sanitária de vetar a produção e comercialização dos anorexígenos: sibutramina, anfepramona, femproporex e mazindol, 28 set. 2011. Disponível em: <

http://www.camara.gov.br/proposicoesWeb/fichadetramitacao?idProposicao=522126 >. Acesso em: nov. 2018.

BRASIL (2011b). Câmara dos Deputados. Projeto de Lei n. 2.734/2011. Altera a Lei n. 9.961, de 28 de janeiro de 2000, que "Cria a Agência Nacional de Saúde Suplementar - ANS e dá outras providências", 17. nov. 2011. Disponível em:

$<$ https://www.camara.gov.br/proposicoesWeb/fichadetramitacao?idProposicao=5277 09\#marcacao-conteudo-portal>. Acesso em: nov. 2018.

BRASIL (2011c). Câmara dos Deputados. Projeto de Lei Complementar n. 7/2011.

Modifica o parágrafo $2^{\mathrm{o}}$ do art. 9o da Lei Complementar $\mathrm{n}^{\mathrm{o}} 101$, de 4 de maio de 2000 Lei de Responsabilidade Fiscal. Disponível em: <

http://www.camara.gov.br/proposicoesWeb/fichadetramitacao?idProposicao $=492008$ >. Acesso em: out. 2018.

BRASIL (2012). Câmara dos Deputados. Projeto de Lei n. 4.030/2012. Estabelece que uma das vagas da diretoria da ANEEL, ANATEL, ANP, ANAC e ANS será preenchida por representante dos consumidores, 06 jun. 2012. Disponível em: < http://www.camara.gov.br/proposicoesWeb/fichadetramitacao?idProposicao=547302 >. Acesso em: 03 ago. 2018. 
BRASIL (2013). Câmara dos Deputados. Projeto de Lei n. 5.737/2013. Acrescenta o art. 5-A à Lei no 9.986, de 18 de julho de 2000, dispondo sobre a nomeação de membros do Conselho Diretor ou Diretoria de agências reguladoras federais. Disponível em: < http://www.camara.gov.br/proposicoesWeb/fichadetramitacao?idProposicao=580184 >. Acesso em: out. 2018.

BRASIL (2013a). Câmara dos Deputados. Projeto de Lei n. 5.810/2013. Dispõe sobre a transparência na tomada de decisão no âmbito das agências reguladoras, 20 jun.

2013. Disponível em: <

http://www.camara.gov.br/proposicoesWeb/fichadetramitacao?idProposicao=581763 >. Acesso em: 03 ago. 2018.

BRASIL (2014). Câmara dos Deputados. Projeto de Lei n. 7.529/2014. Altera a Lei no 9.472, de 16 de julho de 1997, para reservar uma das cinco vagas no Conselho Diretor da Agência Nacional de Telecomunicações para um representante dos usuários, 08 mai. 2014. Disponível em: <

http://www.camara.gov.br/proposicoesWeb/fichadetramitacao?idProposicao=614771 >. Acesso em: out. 2018.

BRASIL (2014a). Câmara dos Deputados. Projeto de Lei n. 8.218/2014. Altera o art. $8^{\text {o }}$ da Lei no 9.986, de 18 de julho de 2000, que "dispõe sobre a gestão de recursos humanos das Agências Reguladoras e dá outras providências", para estender, de 4 (quatro) meses para 6 (seis) meses, o período de quarentena a que está sujeito o exdirigente de agência reguladora, 9 dez. 2014. Disponível em:

http://www.camara.gov.br/proposicoesWeb/fichadetramitacao?idProposicao=819415. Acesso em: 03 ago. 2018.

BRASIL (2015). Câmara dos Deputados. Projeto de Lei n. 845/2015. Altera a Lei no 12.587, de 2012, e a Lei no 10.233 , de 2001, para tratar da informação ao usuário sobre a composição tarifária dos serviços de as passagens do transporte, 19 ma. 2015. Disponível em:

http://www.camara.gov.br/proposicoesWeb/fichadetramitacao?idProposicao=104937 2. Acesso em: 03 ago. 2018.

BRASIL (2015a). Câmara dos Deputados. Projeto de Lei n. 1.539/2015. Estabelece a obrigatoriedade de realização de Análise de Impacto Regulatório - AIR pelas 
Agências Reguladoras no âmbito da Administração Federal, 13 mai. 2015. Disponível em:

http://www.camara.gov.br/proposicoesWeb/fichadetramitacao?idProposicao=127880 7>. Acesso em: 03 ago. 2018.

BRASIL (2015b). Câmara dos Deputados. Projeto de Lei n. 2.845/2015. Dispõe sobre o licenciamento e operação de veículos aéreos não tripulados (VANT"s) e aeronaves remotamente pilotadas (ARP"s), bem como os aparelhos intitulados "DRONES", de emprego militar ou comercial, e dá outras providências, 01 set. 2015. Disponível em: http://www.camara.gov.br/proposicoesWeb/fichadetramitacao?idProposicao=170121 8. Acesso em: nov. 2018.

BRASIL (2015c). Câmara dos Deputados. Projeto de Lei n. 3.041/2015. Acrescenta parágrafo ao artigo 3o da Lei no 5.070, de 7 de julho de 1966, para destinar valores de multas e outras fontes de receita do Fundo de Fiscalização das Telecomunicações FISTEL - exclusivamente à Agência Nacional de Telecomunicações - Anatel, 17 set. 2015. Disponível em:

http://www.camara.gov.br/proposicoesWeb/fichadetramitacao?idProposicao=173450 8. Acesso em: out. 2018.

BRASIL (2015d). Câmara dos Deputados. Projeto de Lei n. 4.113/2015. Altera a Lei no 9.656, de 3 de junho de 1998, que "dispõe sobre os planos e seguros privados de assistência à saúde" e a Lei no 9.961, de 28 de janeiro de 2000, que "cria a Agência Nacional de Saúde Suplementar - ANS e dá outras providências" para destinar ao Fundo Nacional de Saúde a receita proveniente das multas aplicadas pela Agência Nacional de Saúde Suplementar, 16 dez. 2015. Disponível em:

http://www.camara.gov.br/proposicoesWeb/fichadetramitacao?idProposicao=207569 2. Acesso em: 03 ago. 2018.

BRASIL (2015e). Senado Federal. Projeto de Lei n. 241/2015. Modifica o disposto no art. $5^{\circ}$, caput, e revoga o parágrafo único do art. 9º da Lei $n^{\circ}$ 9.986, de 18 de julho de 2000, visando fixar regras para a nomeação de diretor de agência reguladora.

Disponível em: < https://www25.senado.leg.br/web/atividade/materias//materia/120875>. Acesso em: out. 2018. 
BRASIL (2015f). Senado Federal. Projeto de Lei n. 495/2015. Altera as Leis no 9.986, de 18 de julho de 2000; no 6.385, de 7 de dezembro de 1976; no 12.154, de 23 de dezembro

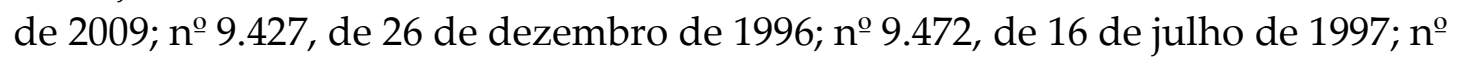
9.478 de 6 de agosto de 1997; no 9.782, de 26 de janeiro de 1999; no 9.961, de 28 de janeiro de 2000, no 9.984, de 17 de julho de 2000, no 10.233, de 5 de junho de 2001, no 11.182, de 27 de setembro de 2005, e a Medida Provisória no 2.228-1, de 2001; com vistas a ampliar a autonomia, a capacidade técnica e os poderes de regulação de mercado das agências reguladoras, da Comissão de Valores Mobiliários (CVM) e da Superintendência de Seguros Privados (SUSEP). Disponível em: < https://www25.senado.leg.br/web/atividade/materias/-/materia/122426>. Acesso em: out. 2018.

BRASIL (2016). Câmara dos Deputados. Projeto de Lei n. 5184/2016. Altera a Lei no 9.472, de 16 de julho de 1997, para modificar critério de escolha dos conselheiros da Agência Nacional de Telecomunicações - Anatel, introduzindo a formação de lista tríplice para posterior escolha e nomeação do Presidente da República, 04 de mai. 2016. Disponível em: < http://www.camara.gov.br/proposicoesWeb/fichadetramitacao?idProposicao=208348 7>. Acesso em: out. 2018.

BRASIL (2016a). Câmara dos Deputados. Projeto de Lei n. 5185/2016. Acrescenta dispositivos à Lei no 9.472, de 16 de julho de 1997, para garantir autonomia financeira e orçamentária para a Agência Nacional de Telecomunicações - Anatel, 4 mai. 2016. Disponível em: http://www.camara.gov.br/proposicoesWeb/fichadetramitacao?idProposicao=208348 8. Acesso em: out. 2018.

BRASIL (2016b). Câmara dos Deputados. Projeto de Lei n. 6.621/2016. Dispõe sobre a gestão, a organização, o processo decisório e o controle social das agências reguladoras, altera a Lei no 9.427, de 26 de dezembro de 1996, a Lei no 9.472, de 16 de julho de 1997, a Lei no 9.478, de 6 de agosto de 1997, a Lei no 9.782, de 26 de janeiro de 1999, a Lei no 9.961, de 28 de janeiro de 2000, a Lei no 9.984, de 17 de julho de 2000, a Lei no 9.986, de 18 de julho de 2000, a Lei no 10.233, de 5 de junho de 2001, a Medida Provisória n⿳⺈ 2.228-1, de 6 de setembro de 2001, a Lei no 11.182 , de 27 de setembro de 2005, e a Lei no 10.180, de 6 de fevereiro de 2001, e dá outras providências. Disponível em: $<$ 
http://www.camara.gov.br/proposicoesWeb/fichadetramitacao?idProposicao=212001 9>. Acesso em: nov. 2018.

BRASIL (2017). Câmara dos Deputados. Projeto de Lei n. 8.460/2017. Altera as Leis n⿳o 9.998, de 17 de agosto de 2000, no 9.472, de 16 de julho de 1997, e no 5.070, de 7 de julho de 1966, autorizando a aplicação dos recursos do Fust na massificação dos serviços de banda larga em áreas não rentáveis e destinando cinquenta por cento dos recursos das taxas de fiscalização do Fistel para o Fust, 04 set. 2017. Disponível em: < http://www.camara.gov.br/proposicoesWeb/fichadetramitacao?idProposicao=215025 8>. Acesso em: out. 2018.

BRASIL (2017a). Congresso Nacional. Lei n. 13.454, de 23 de junho de 2017. Autoriza a produção, a comercialização e o consumo, sob prescrição médica, dos anorexígenos sibutramina, anfepramona, femproporex e mazindol. Disponível em: < http://www.planalto.gov.br/ccivil_03/_ato2015-2018/2017/lei/L13454.htm>. Acesso em: nov. 2018.

BRASIL (2019). Presidência da República. Mensagem n. 266, de 25 de junho de 2019. Disponível em: < http://www.planalto.gov.br/ccivil_03/_ato20192022/2019/Msg/VEP/VEP-266.htm>. Acesso em: jun. 2019.

BRASIL (2019a). Congresso Nacional. Lei n. 13.848, de 25 de junho de 20019. Dispõe sobre a gestão, a organização, o processo decisório e o controle social das agências reguladoras, altera a Lei no 9.427, de 26 de dezembro de 1996, a Lei no 9.472, de 16 de julho de 1997, a Lei no 9.478, de 6 de agosto de 1997, a Lei no 9.782, de 26 de janeiro de 1999, a Lei no 9.961, de 28 de janeiro de 2000, a Lei no 9.984, de 17 de julho de 2000, a Lei $n^{-0}$ 9.986, de 18 de julho de 2000, a Lei no 10.233, de 5 de junho de 2001, a Medida Provisória no 2.228-1, de 6 de setembro de 2001, a Lei no 11.182, de 27 de setembro de 2005, e a Lei no 10.180, de 6 de fevereiro de 2001. Disponível em: < http://www.planalto.gov.br/ccivil_03/_ato2019-2022/2019/lei/L13848.htm>. Acesso em: jun. 2019.

CALDWELL, Michael; MOE, Terry M. The Institutional Foundations of Democratic Government: a Comparison of Presidential and Parliamentary Systems, Journal of Institutional and Theoretical Economics, v. 150, p. 171-195, 1994. 
EGEBERG, Morten. How Bureaucratic Structure Matters: an Organizational Perspective. In: PETERS, Guy B; PIERRE, Jon. Handbook of Public Administration, 2003, p. 116-126.

JORDÃO, Eduardo; MOLHANO, Leandro; SALINAS, Natasha S. C; SAMPAIO, Patrícia. A produção legislativa do Congresso Nacional sobre agências reguladoras, Revista de Informação Legislativa, vol. 56, n. 22, abr./jun. 2019, p. 75-107.

LIPSKY, M. Street-Level Bureaucracy: Dilemmas of the Individual in Public Services. New York: Russell Sage Foundation, 1980.

MCCUBBINS, M. D; NOLL, Roger G; WEINGAST, Barry R. Administrative Procedures as Instruments of Political Control. Journal of Law, Economics and Organization, v. 3, n. 2, p. 243-277, 1987.

MASHAW, Jerry L. Greed, Chaos and Governance. New Haven: CT, Yale University Press, 1997.

MEDAUAR, Odette. A Processualidade no Direito Administrativo. 2.ed. São Paulo:

Revista dos Tribunais, 2008.

MOE, Terry M. The Politics of Bureaucratic Structure. In: CHUBB, John; PETERSON, Paul (eds.), Can the Government Govern? Washington DC: Brookings Institution, 1989, p. 267-329.

NISKANEN, William. Bureaucracy and Representative Government. Chicago: Aldine-Atherton, 1971.

POULANTZAS, H. State, Power, Socialism. Trad. P. Camiller. London: New Left Books, 1978.

SACKS, P. M. State Structure and the Asymmetrical Society, Comparative Politics, v. 12, p. 349-376.

SELZNICK, Philipp. TVA and the Grass Roots: a study in the sociological form of organization. Berkeley: University of California Press, 1949. 
SINCLAIR, Bárbara. Unorthodox Lawmaking: New Legislative Process in the U.S. Congress. 3.ed. CP Press, 2007.

WALDO, Dwight. The Administrative State: a study of the political theory of american public administration. New York: Ronald Press Company, 1948.

WILSON, James. Bureaucracy. New York: Basic Books, 1989.

XAVIER, E. R. Estudo sobre a Autonomia Financeira e Orçamentária da Agência Nacional de Energia Elétrica, analisada a partir do contingenciamento e da vinculação de despesas no orçamento público federal no período compreendido entre 2000 e 2009. Cadernos de Finanças Públicas, Brasília, n. 11, p. 113-135, dez. 2011. Disponível em: < http://www.esaf.fazenda.gov.br/assuntos/biblioteca/arquivosgerais/arquivo.2014-05-21.1470162729>. Acesso em: 02 jul. 2018. 